\title{
Research on the Development of Farmer Cooperatives under the Background of Urban-rural Integration
}

\author{
Qingxiu Peng ${ }^{\mathrm{a}, *}$ and Li Ding ${ }^{\mathrm{b}}$
}

School of Economics and Management, Zhengzhou University of Light Industry, Zhengzhou, China

apengqingxiu@163.com, 594822001@qq.com

*Corresponding author

Keywords: Urban-rural integration, Ecological agriculture, Farmer cooperatives, Family farm.

\begin{abstract}
The integrated development of urban and rural areas has played a facilitating and meditative role. The urban-rural integration has injected liquidity and vitality into farmers' cooperatives, which made the urbanization a reality. However, the movement has also brought challenges to the previous business model. In the new era, it is necessary for the agriculture to transform into a new shape as in family-based unit farm professionalize its utility, lay the foundation for urban and rural economic integration, develop modern environmental friendly agriculture, establish basis for urban and rural social integration, cultivate new forms of professional farmers, provide the main stream force for prospective cultural integration, thrive the rural urbanization movement from its fluent liquidity and become the glue of this integrated development.
\end{abstract}

\section{Introduction}

The integration is to see the relationships between industry and agriculture, countryside and cities, and urban-rural residences as one unit for planning, facilitating and construction. The urban planning, industry development, marketing information development, policy making, and eco-environment protection that are involved are to be seen as one unit. According to the Third Plenary Session of the 18th Central Committee of the Communist Party of China, three issues that are concerning agriculture, countryside and farmers, lay their fundamental resolutions in urban and rural unionizing development. The committee also pointed the necessity to build a reliable system and its mechanism in order to form new types of industry-agriculture urban-rural relationship which will benefit the chances for farmer groups to participate and share the blossom of modernization.

\section{New Challenges Brought by Urban-Rural Integration to the Development of Farmers' Cooperatives}

\subsection{Challenges to Traditional Agriculture: The Modernization and Eco Environment Friendliness Required by the Integration}

Ever since the implementation of new countryside establishment strategy, farmers' cooperatives have been the main role of resolving the aforementioned "three issues", not only in large scales but also at a high quality standard. However, from the actual stances, most cooperatives are still formed by farmer families. The previous outsourced farming land and business management given by farmer families is too fractured to realize a large scale mass production, modernization and mechanization.

\subsection{Challenges to Financial Services: Contrasts between Two Societies; Financing Shortages}

Law of the People's Republic of China on Farmers' Professional Cooperatives (2017 Revision), article fifty, has announced that central and municipal finance should separate their functions in supporting farmers' cooperatives establishment. From the national to the local administrations, measures to encourage and develop farmers' cooperatives have been established. However due to the 
limitation of financial support, especially village and county levels lacks special financing, these measures haven't been practical. What deserves more attention is that the difference between urban and rural financing procedures, driven by uncomprehensive accounting systems, untransparence, lack of mortgage and sponsorship, barriers exist on every single level for the cooperatives to march forward. Financing groups, counted as vital tools for supporting farmers' cooperatives to grow, have yet put their capabilities into practice.

\subsection{Impacts to the Cooperatives Competitions: Urban Capitals Flooding to Rural Development and New Economics Strive Within}

The "No. 1 Central Document" has released the spirit to encourage and guide urban capitals to countryside to develop appropriate business of crop farming. The capital entering farms stimulates all sorts of farming corporations, family farms, company farms and union farm corporations to develop. These agricultural enterprises target precisely in marketing and seek to maximize profitability. Their market principles are well developed and they embody a very strong competence in competition. Their cunning info-gathering network and multi-benefit format will indeed bring huge impact towards the farmers' cooperatives.

\subsection{Challenges to the Liquidity of Countryside: Small Scales and Low Efficiency of Farmers' Cooperatives}

The most common liquidity of information and business are mostly individual business representatives or the best business in town. Not only is it running on low efficiency but also at high risks and costs. It is difficult for them to compete against the urban stream. Long formatted by the national dual economical structure, the circulation system of rural and urban areas has developed into two uncooperative ways. Most of the time, rural organizations are smaller scale with low production focus and low liquidity. Under these circumstances, the productivity and people's consuming capacity have not grown. Facing the urban organizations, they are apparently the vulnerable side. This status has severely influenced the integration development movement.

\section{Political Suggestions to Advance Farmers' Cooperatives under the Integration of Urban and Rural Development}

\subsection{Productive Families Reforming into Farms, Establishing Foundations for Economics Integration}

In the economics where small scales of farming were focused, traditional agriculture was in nowhere to be transformed to a modern one. Industrialization and urbanization was also out of range. Therefore to realize the industrialization, urbanization and agricultural modernization, it was to focus on expanding the scales of the business model. As the new body of agriculture business, family farms have their advantages as in not only is it satisfying the special needs of biological traits of agriculture production as well as many other needs, but also does it focus on producing to commercialize and maximize the benefit. What's more, family farms enlarge the size of each producer's farming land and suppressed the previous drawbacks caused by management fragmentation of lands and also improved the agriculture mechanization level. Not only does facilitate infrastructure establishment and supporting facilities construction, but also benefit shortening urban and rural income gaps.

\subsection{Developing Modernized Environment Protective Agriculture, Beautifying Countryside, and Laying Foundations for Urban - Rural Society Integration}

The integration movement emphasizes the protection to countryside environment. It aims to save the nature for cities and spare the tradition and unsophisticatedness for rural areas. Thus the farmers' cooperatives must take the path with economization, "green-low-carbon" towards environment protection.

a) Recycle agricultural resources to development eco-agriculture such as Xichuan county’s active 
exploration in Henan Province. People there focused on feeding paddlefish that purifies water. This kind of aquiculture was named after the lake Danjiang as Danfish.

b) Farmers' cooperatives combine agriculture tourism for mutual benefit. On one hand this enriches city and villages recreational activities. On the other hand, this increases incomes for agriculture that will be used to facilitate the construction of its modernization, professionalization and productivity.

c) Fine machinery increases values. Stone mortar grinded chili is a very outstanding traditional agricultural production amongst many others. Now stretching the producing chain, nurturing extraordinary industry clusters, and co-operate with companies and factories that specialize in mass production, a new formality of agriculture-industry complementation and facilitation has been created.

\subsection{Nurturing New Types of Farmers to Provide New Force for the Cultural Integration}

"New farmers" is one big amendment reported in government new policies. The new form of professional farmers is going to be the stem body of new market. They see farming as their life-long profession and always seek the best benefit. Not only equipped with literacy, techniques, high social moral standards and management skills, but they also create benign effects to ecology, environment and social tiers. Therefore given the time to distribute resources, they will be able to make the land sustainable in producing, improve productivity and thrive. Nurturing these new farmers, its profit will show in the future. On one hand all sorts of resources are live as running streams; government sees the importance to build sponsorship towards market and education. On the other hand policy making will draw back business starters who once left countryside for urban life, as well as retired/discharged soldiers, graduates from colleges. Man power from all over the society will inject into family farms and become new "farmers".

\subsection{The Integration of Liquidity - It's Time to Glue Them Together}

Blended into integration movement, in order to develop modern agriculture and improve information circulating efficiency, it is necessary to integrate both rural and urban circulation system. Additionally, villages' infrastructure construction has to be listed on schedule. Schultz believes for infrastructures in rural areas drive ways will just appropriately solve the problems of circulation costs and value depreciation. On one hand government keeps investing in infrastructure building to facilitate agriculture modernization and industrialization. One the other, it is to explore effective financing options. It would also greatly help improve the management and utility of countryside infrastructure facilities.

\section{Summary}

With the land circulations being fastened, land resources being assembled to relatively bigger business, and industrial - commercial financing flooding into urban - rural integrated agriculture environment, the movement of farmers' cooperatives is to merge with government support and marketing mechanisms in order to better explore its journey in the history. According to the fundamental realities of our nation and the temper of times, with the plan of regional differences, phase difference and industry difference gaps being shortened all taken into consideration, the key to realize rural and urban areas integration is to enforce family unit based farms and keep nurturing new farmers, in addition to further develop ecological, modern and sustainable agriculture.

\section{Acknowledgments}

This research was financially supported by: 2017BJJ075; 2018-ZZJH-616; 182400410151. 


\section{References}

[1] Yu shunhe, zheng meiling, Development status of farmers' professional cooperatives and innovative development strategies, J. rural science and technology, 2016(33).

[2] Zhu yong, Research on the standardized development of farmers' professional cooperatives, J. Modern agricultural science and technology, 2016(12). 